\title{
事例解析：高温純水中における炭素鋼鋼管壁の異常減肉*
}

\author{
松 村 昌 信** \\ ** 広島大学 名誉教授
}

\section{A Case Study of Unusual Corrosion Damage in a Carbon Steel Pipe Wall Carrying Pure Water at Elevated Temperatures}

\author{
Masanobu Matsumura** \\ ** Professor Emeritus, Hiroshima University
}

\begin{abstract}
The case cited here occurred in a waste heat boiler plant in 1993, which has many features in common with the case of Mihama nuclear power plant in 2004 in terms of piping materials, environmental conditions as well as in the location where the damage took place: very close to an upstream flow-meter. On this case, the cause was analyzed based on the best available knowledge and seemingly the best countermeasures for preventing a recurrence were taken. Seven years after the accident, in 2000, the effectiveness of these countermeasures was examined. The results of the examination and the newly obtained knowledge from the Mihama's case together confirmed the rationality of the opinion that the unusual thinning of pipe wall can be attributed not to the turbulence in fluid flow, but to a macro-cell corrosion.
\end{abstract}

Key words : turbulence, macro-cell corrosion, boiler feed water, unusual thinning of pipe wall, carbon steel pipe.

\section{1. 緒}

古くは 1986 年のサリー原発，最近では 2004 年の美浜 原発における破裂事故のように，ボイラー給水を輸送す る炭素鋼鋼管の異常減肉を原因とする事例が，上記のほ かにも引き続いて発生している。これらの事例が共通し て我々を悩ます点は, 高い減肉速度 $\left(0.5 \sim 1.0 \mathrm{~mm} \mathrm{y}^{-1}\right)$ と ${ }^{1)}$, その偶発性 (同一条件下でも減肉が発生したり発生 しなかったりすること）である。これらの現状は，この 種の異常減肉の発生機構が解明されていないことばかり でなく, 関係因子さえも充分には把握されていないこと を意味し, 適切な再発防止対策を立てることが出来な い.

以下に採り上げるのは，1993 年に国内の或る廃熱ボイ ラープラントにおいて発生した事例で，配管や環境条件， 破損の状況などに関して美浜原発の事例と多くの共通点 がある。この事例については当時の知見に基づいて厳密 な解析が行われ, 最善と考えられる再発防止対策が執ら れた。それから 7 年が経過した 2000 年に行われた当該 箇所の検査の結果は，その対策が適切であったかどうか を検討するためにも，また，今後運転を再開する美浜原 発における事故再発防止詨策の効果を予測する上でも参 考になることが多いと思われる。ただし，上記のように この異常減肉発生の偶発性がいまだ解明されていないの で，異常減肉が再発していない場合でも適切な対策であ ったと判定することはできない。一方, 異常減肉が再発 した場合は，原因の推定あるいは対策施工の内の少なく ともどちらかが適切ではなかったと判定される.

この事例については, 幸いにも減肉発生場所ばかりで

* 材料と環境 2006 (つくば, 2006年) にて発表

** テ739-0031 東広島市西条町福本 237-101 (Saijo, Fukumoto 237101, Higashi-Hiroshima, 739-0031 Japan)
なくその周辺についても詳細な調査記録2) が残されてい た（当該事業所のご厚意により本稿ではそれらをそのま まデータとして用いた). 先般の美浜原発事故はそれに さらに新しいデー夕を加えたことになる。それらのデー 夕を活用して、本件における異常減肉の発生機構と, そ れに基づく再発予防対策の検討を行うことができた。

\section{2. プラントの状況}

Fig. 1 は当該の廃熱ボイラープラントの給水配管系統 図である.タンクに保有されている純水は，ポンプ出口 で脱酸素剤としてヒドラジンおよび $\mathrm{pH}$ 調整用の中和性 アミンを注入されて脱気器に入り，ここで溶存酸素が除 去された後, 給水ポンプで各ボイラーへ供給される．本 プラントは 1977 年に稼動運転を開始したが，その 15 年 後の 1993 年に, 流量計の下流に設置されていた炭素鋼 鋼管が破損した. 破損を生じた箇所は $\mathrm{A}, \mathrm{B}$ の 2 系列の内, $\mathrm{B}$ 系配管に設置されているフローノズル型流量計 (FIC4521）の下流である．当該の配管仕様および環境・運転 条件は Table 1 の通りである。これらの諸条件は，管内 径（美浜原発では $520 \mathrm{~mm}$ ) およびボイラー給水の温度 (美浜原発では $142^{\circ} \mathrm{C}$ ) 以外は美浜原発の事例におけるそ れらに酷似している。 なお, 美浜原発の事例でも同じ条 件で A, B 2 系列の配管が並列で運転されていたが，その 内の A 系列の鋼管が破裂した。

\section{3. 破損部および類似箇所の概要}

Fig. 2 には，B系列の配管（FIC-4521）の破損後のスケ ッチと, スケッチに示した測定点における残留肉厚が示 されている．減肉は測定点 5 から 0 に向かって大きくな り，鋼管とフランジを接合する溶接線の直ぐ下流では $0.63 \mathrm{~mm}$ (測定された内の最小值)まで減肉していた。稼 動時間に基づいて平均減肉速度を算出したところ 0.54 


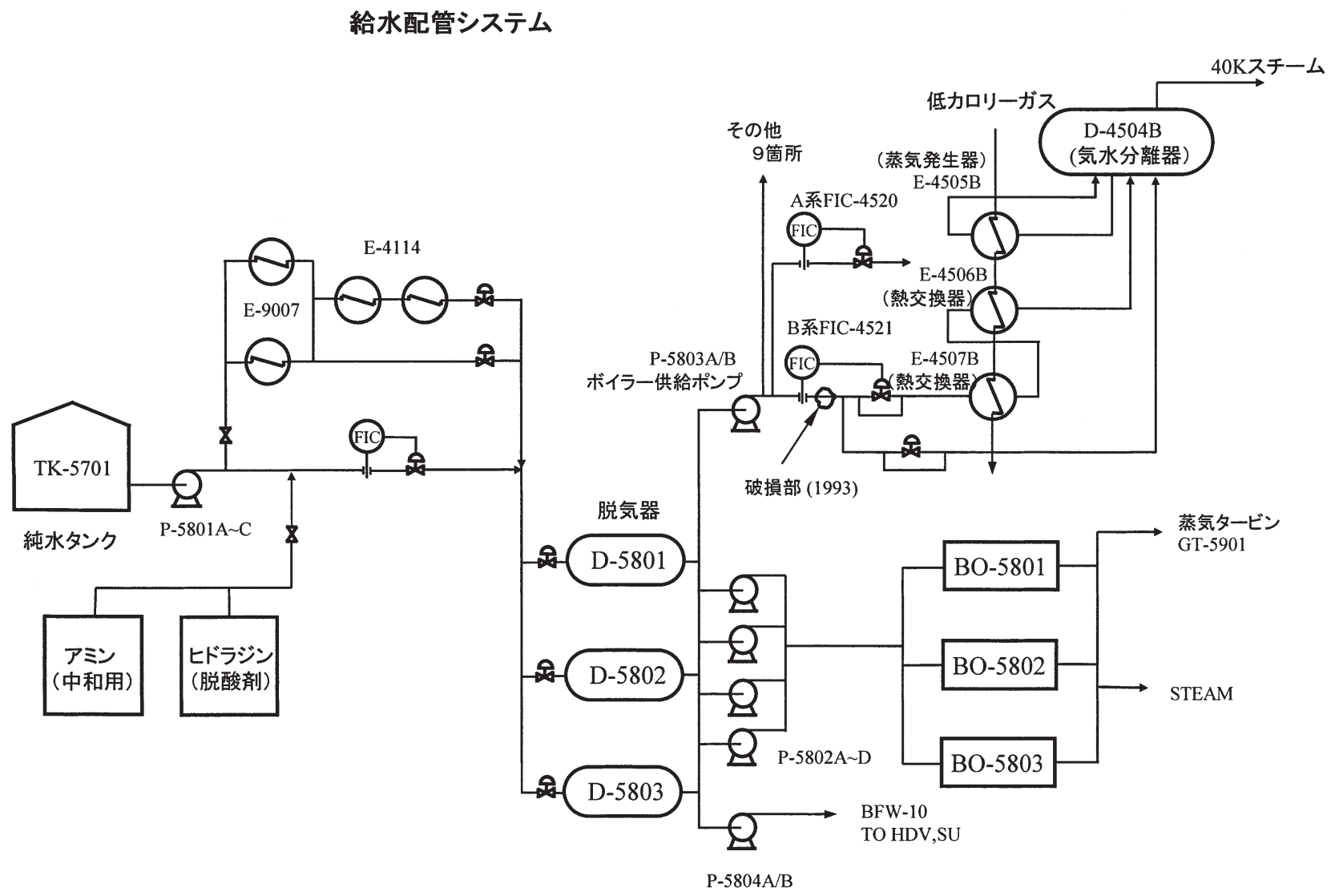

Fig. 1 Flow diagram of the waste heat boiler plant ${ }^{2}$.

Table 1 Plant operating conditions.

Specifications for the piping tube:

$\begin{array}{lc}\text { Material of tube } & \begin{array}{l}\text { STPT 370 (Carbon steel tube for } \\ \text { high temperature use) }\end{array} \\ \text { Nominal diameter } & \text { 4B SCH } 80 \\ \text { Outside diameter } & 114.3 \mathrm{~mm} \\ \text { Inside diameter } & 97.1 \mathrm{~mm} \\ \text { Nominal wall thickness } & 8.6 \mathrm{~mm}\end{array}$

Environmental and flow conditions:

$\begin{array}{ll}\mathrm{pH} & 8.5 \sim 9.5 \\ \text { DO } & <0.005 \mathrm{mg} \mathrm{L}^{-1} \\ \text { Temperature of fluid } & 123^{\circ} \mathrm{C} \\ \text { Flow velocity } & 1.9 \mathrm{~m} \mathrm{~s}^{-1} \text { (main flow), } 4.1 \mathrm{~m} \mathrm{~s}^{-1} \text { (flow nozzle) }\end{array}$

$\mathrm{mm} \mathrm{y}^{-1}$ となった。 また，この $\mathrm{B}$ 系列に並行する $\mathrm{A}$ 系列 では $5.4 \mathrm{~mm}$ の減肉があり, 平均減肉速度は $0.36 \mathrm{~mm} \mathrm{y}^{-1}$ であった (Table 2). 破損が生じた箇所では管壁がまるで 紙のようにほぼ均一に薄くなっていた点は, 美浜原発の 事例において破裂した A 系列の鋼管の場合とよく似てい る. 一方, 各測定点における周方向の減肉分布はほほ均 一であった。この点は, 管の天井部と管底部に著しい偏 りのあった，美浜事例の A 系列鋼管の場合とは異なる. Fig. 3 は破損した鋼管に溶接接続されていたフランジの 外観である。このフランジに関しては第 6 章で詳しく検 討を行う。

この廃熱プラント内で, 破損部と類似した箇所につい て肉厚測定が行われ, その結果と稼働時間とからそれぞ
れの箇所の平均減肉速度が算出された (Table 3). 当該の 2 箇所 (FIC-4520，-4521）および別の 1 箇所 (FI-5878)の 減肉速度は, プラント内の他の流量計下流部の減肉速度 $0.02 \sim 0.31 \mathrm{~mm} \mathrm{y}^{-1}$ に比較して確かに高い.

\section{4. 当時推定された破損の原因と再発防止対策}

本事例の鋼管が破損した直接の原因に関して，当該の 運転条件下でのボイラー構造に基づく強度計算上の必要 肉厚は $0.84 \mathrm{~mm}$ であり, この值以下に減肉したために破 損が生じたと推定された。次に, その減肉が生じた原因 について検討が行われた。ボイラー給水の腐食性には, 溶存酸素濃度, $\mathrm{pH}$, 流速 (乱流), 温度などの因子が影 響するが，当該プラントでは同一給水源から各所に供給 するシステムであるので, 溶存酸素濃度, $\mathrm{pH}$, 温度は同 一であったと考えられる。従って, 破損した FIC-4521 系配管が著しく高い腐食速度であったのは, 流動条件の 違いであったと考えざるを得なかった。すなわち流量計 FIC-4521 の下流に他の流量計の下流よりも高い乱流を生 じさせた固有の因子があったと考えられ，『当該の箇所 ではフランジと配管の溶接部内面がスムースでなく凹凸 形状が微妙に影響して乱流の度合いが高かったため腐食 速度が上昇した』と推定された。

異常減肉の再発防止対策としては, Table 3 で深い減肉 が認められた 3 箇所の流量計について, それらの下流部 の配管を更新したとき溶接の第一層目は TIG 溶接を行っ て溶接内面をスムーズに仕上げた。また，定期修理時に は, 内面の形状も分かる $\gamma$-RAY 検査を主体に検査頻度 
破損配管 (FIC-4521) 及びFIC-4520下流肉厚測定結果

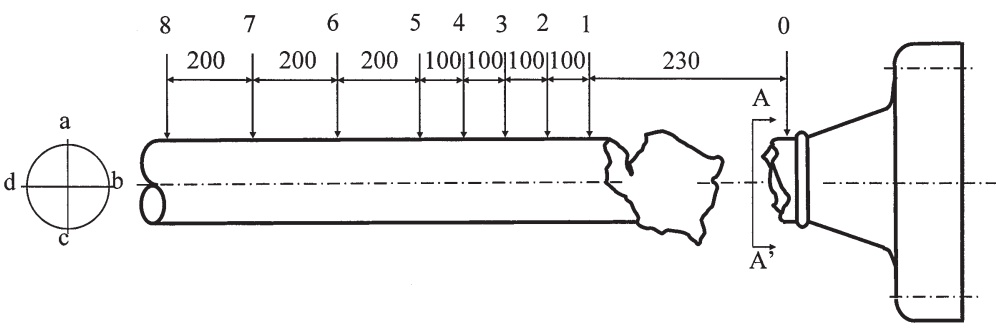

B系:FIC-4521 下流直管部肉厚測定結果 単位 $(\mathrm{mm})$

\begin{tabular}{|c|c|c|c|c|c|c|c|c|c|}
\hline 位置 & 8 & 7 & 6 & 5 & 4 & 3 & 2 & 1 & 0 \\
\hline a & 7.3 & 7.2 & 7.0 & 6.8 & 6.4 & 6.4 & 3.8 & 2.5 & 1.82 \\
\hline $\mathrm{b}$ & 7.5 & 7.2 & 7.2 & 7.0 & 6.4 & 5.2 & 3.6 & 2.3 & 1.74 \\
\hline $\mathrm{c}$ & 7.2 & 7.9 & 7.6 & 7.4 & 6.6 & 5.6 & 3.8 & 2.6 & 1.63 \\
\hline $\mathrm{d}$ & 7.1 & 7.2 & 7.2 & 6.7 & 6.4 & 5.4 & 3.7 & 2.4 & 0.63 \\
\hline
\end{tabular}

Fig. 2 The sketch of ruptured pipe and flange ${ }^{2)}$.

Table 2 Average thinning rates of pipe wall.

\begin{tabular}{lcc}
\hline $\begin{array}{c}\text { Depth of wall thinning } \\
\text { in 15 years, } \mathrm{mm}\end{array}$ & $\begin{array}{c}\text { Average wall thinning } \\
\text { rate, } \mathrm{mm} \mathrm{y}^{-1}\end{array}$ \\
\hline Line A (FIC-4520) & 5.4 & 0.36 \\
Line B (FIC-4521) & 8.0 & 0.54 \\
\hline
\end{tabular}

を増やし，確実な安全管理を継続することとした。

\section{5. 再発防止対策の効果}

2000 年 6 月に FIC-4520, -4521 の下流に設置された配 管について検査を行った結果， $2.6 \mathrm{~mm}$ および $3.3 \mathrm{~mm}$ の 減肉が認められた。稼動年数 7 年として算出された減肉 速度は 0.37 および $0.47 \mathrm{~mm} \mathrm{y}^{-1}$ となる (Table 4). B 系 列の值は改修前に比べて幾分低いが，A系列ではかえっ

なかった。

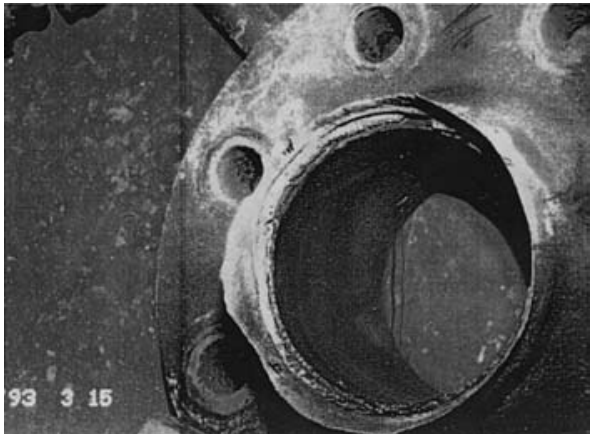

Fig. 3 The appearance of the joint between steel pipe and flange ${ }^{2)}$.

て高くなっているので異常減肉が再発した と判定せざるを得ない。すなわち，本件の 再発防止対策は期待された効果を発揮でき

\section{6. 新しい知見から推定される異常減肉の発生機構}

上記の防止対策が効果を発揮できなかった理由とし て，次の 2 つが考えられる。

（1）原因推定が間違っていた.

（2）原因推定は正しかったが，溶接施工が不完全で あった。

減肉の発生箇所がオリフィスの下流であったことを考 慮すると，防止対策が失敗した理由は上記の (1)である と思われる。 その根拠はオリフィス下流に発生する二次 流れである. Fig. 4 に示すように，オリフィス下流の管 壁表面上には，本流とは速度の異なる二次流れあるいは 淀み流域が発生する。 その流れ方向は本流とは逆方向で ある．従って，オリフィスと鋼管の間に高い溶接裏波が 存在したとしても，そこの流れに発生する乱れの影響を

Table 3 Pipe wall thinning rates at locations downstream from flow-meters in the plant ${ }^{2}$.

\begin{tabular}{|c|c|c|c|c|c|c|c|c|c|c|c|c|c|c|c|}
\hline \multirow[b]{2}{*}{ ITEH } & \multirow[b]{2}{*}{ SERVICE } & \multicolumn{4}{|c|}{ 进転采作（幥河） } & \multirow{2}{*}{\begin{tabular}{|c|}
$D_{1}$ \\
配䋿山徍 \\
\\
$\mathrm{mm}$ \\
\end{tabular}} & \multirow{2}{*}{\begin{tabular}{|c|}
$d_{i}$ \\
$f^{\prime} \%$ 难 \\
\\
$\mathrm{mm}$ \\
\end{tabular}} & \multirow[t]{2}{*}{$\mathrm{di} / \mathrm{Di}$} & \multicolumn{2}{|c|}{$\begin{array}{r}\text { 流 述 } \\
\text { 回 } / \mathrm{sec} \\
\end{array}$} & \multicolumn{3}{|c|}{ 肉厚 } & \multirow{2}{*}{$\begin{array}{c}\text { 展食速度 } \\
\mathrm{mm} / \mathrm{y}\end{array}$} & \multirow{2}{*}{ 觰 考 } \\
\hline & & $\underset{\mathrm{Kg} / \mathrm{GM} 2 \mathrm{G}}{\mathrm{F}}$ & $\begin{array}{l}\Delta P \\
\operatorname{mmll} 20\end{array}$ & $\begin{array}{l}\text { 温度 } \\
{ }^{\circ} \mathrm{C}\end{array}$ & $\begin{array}{c}\text { 流星 } \\
T / H\end{array}$ & & & & 配 管 & 扠\%石 & 公 你 & 最小必界 & 測起值 & & \\
\hline il-5874 & BO BFW P5802A FLCI & 89.0 & 2,820 & 123 & 95.0 & 139.1 & 67.6 & 0.19 & 1.87 & 7.90 & 13.1 & 7.5 & 9.5 & 0.31 & \\
\hline EI-5875 & BO BFW P5802B FLCI & 89.0 & 2,820 & 123 & 95.0 & 139.1 & 67.6 & 0.19 & 1.87 & 7.90 & 13.1 & 7.5 & 9.5 & 0.31 & \\
\hline FI-5876 & Bo BFW P5802C, FLCI & 89.0 & 2,820 & 123 & 95.0 & 139.1 & 67.6 & 0.19 & 1.87 & 7.90 & 13.1 & 7.5 & 10.9 & 0.19 & \\
\hline FI-5877 & BO BFW P5802D FLCI & 89.0 & 2,820 & 123 & 95.0 & 139.1 & 67.6 & 0.49 & 1.87 & 7.90 & 13.1 & 7.5 & 10.9 & 0.19 & \\
\hline$E I-5817$ & BO5801 INJ WATER & 89.0 & 64 & 123 & 8.0 & 97.1 & 62.5 & 0.64 & 0.32 & 0.78 & 8.6 & 5.2 & 8.0 & 0.04 & \\
\hline EI-5827 & BO5802 INJ WATER & 89.0 & 61 & 123 & 8.0 & 97.1 & 62.5 & 0.64 & 0.32 & 0.78 & 8.6 & 5.2 & 8.3 & 0.02 & \\
\hline EI-5837 & B05803 INJ WATER & 89.0 & 61 & 123 & 8.0 & 97.1 & 62.5 & 0.64 & 0.32 & 0.78 & 8.6 & 5.2 & 8.3 & 0.02 & \\
\hline FI-5878 & BFH40 P5803A FLCI & 56.0 & 11,680 & 123 & 145.0 & 193.0 & 59.3 & 0.31 & 1.48 & 15.70 & 11.7 & 6.2 & 6.8 & 0.34 & 扠クイ下流配管更新 \\
\hline FI-5805 & EXPORT BFH40 & 56.0 & 811 & 123 & 145.0 & 193.5 & 111.3 & 0.57 & 1.18 & 4.46 & 11.7 & 6.2 & 8.9 & 0.19 & \\
\hline FC-2201 & BFW40 TO D2203 & 56.0 & 711 & 123 & 16.0 & 73.9 & 46.8 & 0.63 & 1.12 & 2.79 & 7.6 & 2.6 & 6.8 & 0.06 & \\
\hline $\mathrm{FI}-6572$. & BFW40 TO IIP & 56.0 & 100 & 123 & 40.0 & 190.9 & 91.4 & 0.48 & 0.41 & 1.79 & 12.7 & 6.2 & 10.3 & 0.17 & \\
\hline FI-4307. & BFW40 TO D4309 & 56.0 & 784 & 123 & 56.0 & 143.2 & 88.7 & 0.62 & 1.02 & 2.65 & 11.0 & 4.8 & 10.8 & & \\
\hline$F[-4366$ & BFW4O TO DSH4301 & 56.0 & 277 & 123 & 0.4 & 19.5 & 10.2 & 0.21 & 0.06 & 1.43 & 5.5 & 1.7 & 3.4 & 0.15 & \\
\hline FIC-4520 & BFH40 TO E4507A & 56.0 & 667 & 123 & 31.0 & 97.1 & 67.1 & 0.69 & 1.23 & 2.57 & 8.6 & 3.4 & 3.5 & 0.36 & 狮れイ下流配管更新 \\
\hline FIC-4521 & BFW10 TO E1507B & 56.0 & 1.406 & 12.3 & 50.0 & 97.1 & 67.1 & 0.69 & 1.98 & 4.14 & 8.6 & 3.1 & 1.0 & 0.51 & 扠7ィ不下流配管更新 \\
\hline FI-5806 & EXPORT BFW10 & 19.0 & 756 & 123 & 70.0 & 154.1 & 111.5 & 0.74 & 1.13 & 2.04 & 7.1 & 1.7 & 5.8 & 0.09 & \\
\hline FI-5908 & TIC5906 BFW & 19.0 & 100 & 123 & 1.6 & 38.4 & 24.9 & 0.65 & 0.11 & 0.99 & 5.1 & 0.5 & 3.5 & 0.11 & \\
\hline FLC-5880 & BFW10 P58011 FLCI & 19.0 & 1,761 & 123 & 70.0 & 151.0 & 82.7 & 0.55 & 1.17 & 3.91 & 7.1 & 1.6 & 5.3 & 0.13 & \\
\hline FI-5818 & BO-5801 BLOW & 67.0 & 351 & 291 & 0.8 & 38.4 & 13.9 & 0.38 & 0.26 & 2.0 & 5.1 & 1.7 & 1.1 & 0.07 & \\
\hline FI-5828 & Bo-5802 BLOW & 67.0 & 351 & 291 & 0.8 & 38.4 & 13.9 & 0.36 & 0.26 & 2.0 & 5.1 & 1.7 & 4.1 & 0.07 & \\
\hline FI-5838 & Bo-5803 BLOW & 67.0 & 351 & 291 & 0.8 & 38.4 & 13.9 & 0.36 & 0.26 & 2.0 & 5.1 & 1.7 & 4.1 & 0.07 & \\
\hline
\end{tabular}


Table 4 The performance of countermeasure.

\begin{tabular}{lcc}
\hline & \multicolumn{2}{c}{ Average wall thinning rate, $\mathrm{mm} \mathrm{y}^{-1}$} \\
\cline { 2 - 3 } $\begin{array}{c}\text { Before the rupture } \\
(1977 \sim 1993)\end{array}$ & $\begin{array}{c}\text { After the renewing } \\
(1993 \sim 2000)\end{array}$ \\
\hline Line A (FIC-4520) & 0.36 & $0.37(2.6 / 7)$ \\
Line B (FIC-4521) & 0.54 & $0.47(3.3 / 7)$ \\
\hline
\end{tabular}

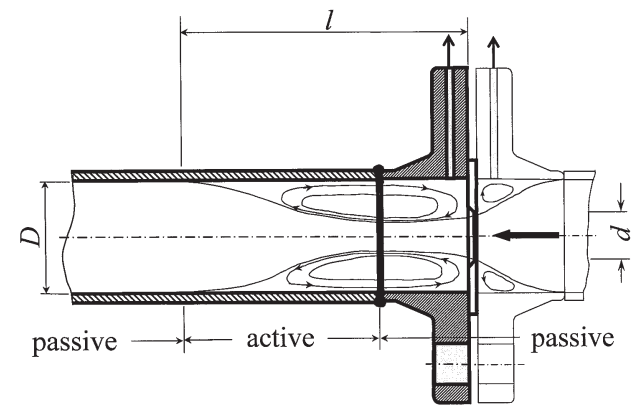

Fig. 4 The range of secondary flow and corrosion damage in the downstream of flow meter.

受けるのはフランジの内面であっても管内面ではない. 従って，管内面に発生した減肉を高い㙜波に帰すのは明 らかに間違っている。また，本件と美浜の事例とを比較 をすると，美浜では，はめ达み型のフランジを用いてい たので溶接裏波は生じない。 それでもオリフィス下流に 異常減肉が生じているので, 美浜の事例と本事例は同一 の原因で発生したという想定の下では，この点からも裏 波原因説は否定される.

ここで改めて当該の鋼管の上流側に溶接されていたフ ランジ (Fig. 3) を観察すると, 紙のように薄くなってい る管壁とは対照的に, フランジの内壁にはほとんど減肉 が生じていないことが認められる。 このフランジの材質 は上記のように特殊鋼に分類される高級材の S $25 \mathrm{C}$ (機械 構造用炭素鋼鋼材）である。これらのことから，このフ ランジをマクロカソード，鋼管部をマクロアノードとす る異種金属接触に起因するマクロセルが形成された可能 性がある。しかし，

(a) 鋼管材料 STPT もフランジ材料 S $25 \mathrm{C}$ も本質は炭 素鋼であってアノード分極挙動に大差が生じること は考えにくい.

（b）下流側のフランジに接する鋼管には隇肉が生じた が，上流側の鋼管には生じなかった理由を説明でき ない.

従って，この異常減肉を異種金属接触腐食に帰すには 無理があると認めざるを得ない.

ところで美浜原発の事例でも A, B 系ともにオリフイス の下流側には深い減肉が生じたが，上流の配管には全く 減肉は生じていなかった。また，下流に生じた減肉域の 広がり $e[\mathrm{~mm}]$ は Fig. 5 に示されるようにオリフィスか ら下流方向へ $3000 \mathrm{~mm}$ 近くまで達していた ${ }^{3)}$.これは管 内径 $D(520 \mathrm{~mm})$ の約 6 倍である。一方, Fig. 4 に示し たオリフィスの下流の淀み流域の範囲 $l$ は, 一般にオリ フィスの開口面積比 $m=(d / D)^{2}$ の関数であり, それが小 さいほど $l$ は大きく, 最大で $6 D$ である ${ }^{4)}$.美浜原発の才

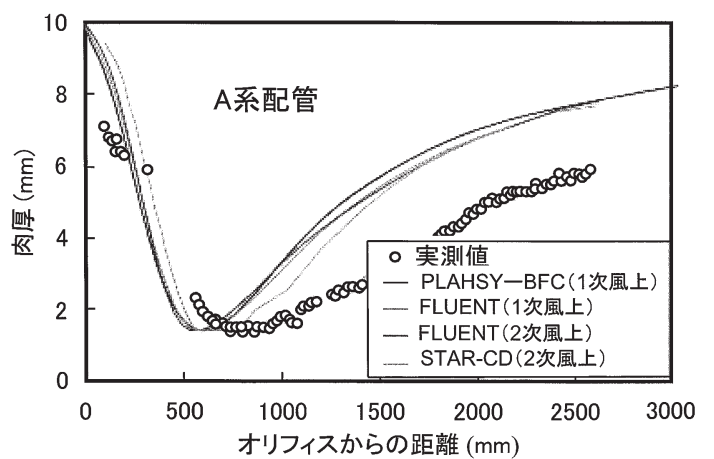

Fig. 5 Distribution of residual pipe wall thickness in Mihama's case $^{3)}$.

Table 5 The range of corrosion damage at the downstream of flow-meter.

\begin{tabular}{lcccc}
\hline & $D[\mathrm{~mm}]$ & $m[-]$ & $e[\mathrm{~mm}]$ & $e / D[-]$ \\
\hline This case & 97.1 & 0.48 & 630 & 6.4 \\
Mihama's case & 520 & 0.39 & 3000 & 5.8 \\
\hline
\end{tabular}

リフィスの開口面積比は 0.39 と充分小さいので $l$ は $6 D$ であると思われる。すなわち, 減肉域と淀み流域の広が りが一致している。また, 本事例の減肉域の広がりは Fig. 2 の減肉分布の表に示されているように $630 \mathrm{~mm}$ (測 定点の 0 と 1 との間隔は $230 \mathrm{~mm}$ ) であり, 管内径が $97.1 \mathrm{~mm}$ であるので, この場合もほぼ $6 D$ になり減肉域 は淀み流域と一致する (Table 5).

本事例でも美浜原発の事例でも, 減肉領域と淀み流域 がほぼ一致した理由は次のように説明できる。一般に炭 素鋼は常温の純水中では不動態化しないが，条件によっ ては $150^{\circ} \mathrm{C}$ 付近から不動態化の兆しが現れ， $250^{\circ} \mathrm{C}$ 付近で はほぼ完全に不動態化する5)。これは炭素鋼の不動態化 を決定するフラーデ電位が環境温度の上昇と共に降下す るためであろう。フラーデ電位は, 温度のほかに $\mathrm{pH}$, 鉄鋼材料中に含まれるクロムなどの合金成分の濃度に依 存するが, 環境中の溶存酸素濃度には依存しないと考え られている。しかし, それは溶存酸素濃度が充分高い場 合であろう. 最近の研究によると, 純水中の炭素鋼が腐 食からまもられるためには, 炭素鋼表面において $1 \mathrm{ppb}$ 以上の溶存酸素が必要であると報告されている6 ${ }^{6}$. 本事 例の場合, 沖合いの溶存酸素濃度は $5 \mathrm{ppb}$ 程度であるの で通常の管内流れではこの濃度がたもたれて不動態化し たものの, 流れの淀み流域では物質移動速度が遅く, 管 壁表面ではこの濃度に達しなかったため不動態化されな かった可能性がある。 その結果これらの流域に, 活性態 /不動態形のマクロセルが形成されたと考えられる。い ったんマクロセルが構成されると, マクロセル電流掞よ び面積比効果によって通常の腐食より高い速度で腐食が 進行する。そのため鋼管内面に深い減肉が生じたと思わ れる.

また，本事例については，A，B 系列ともに下流側のフ ランジは溶存酸素濃度の低い淀み流域にあったものの, 鋼管よりも高級材であったためその内表面は不動態化し ていたものと思われる.すなわち，本事例では Fig. 4 に 示すような不動態域と活性態域からなるマクロセルが形 
成されたものと想像される.

本事例の廃熱ボイラーシステムに設置された 21 基の 流量計の内, 当該の 3 基だけに異常減肉が発生した理由 を明かすヒントは Table 3 にある，すなわち，これらの 3

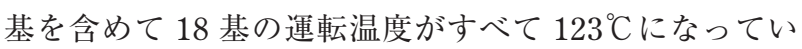
る。これは，実際に温度の測定が行われたのは 1 箇所だ けで, 他の 17 基の流量計の運転温度にはそれを当てた ものと思われる. しかし, 当該の 3 基は, 脱気器の直ぐ 近くに設置されているので, 温度測定が行われた場所の それに比べて温度が高く, 実際は一般に異常減肉が頻発 する $140^{\circ} \mathrm{C} に$ 近い温度にあったものと想像される。

\section{7. 再発防止対策}

本事例の原因を異種金属接触腐食とみなした場合の再 発防止対策を Fig. 6 の左側に示した. 突合せ溶接式に代 えてスリップオンタイプのフランジを採用し, 環境夜内 におけるフランジ材と管材との接触をさけ，さらに管材 と共材のオリフィスを用いて系内から異材を排除する. 一方，その原因を淀み域における活性態域とその周辺の 不動態域からなるマクロセルと考えるのであれば，さら に Fig. 6 の右図に示したようにオリフィスに換えて全圧 管 (ピトー管) を採用し, 淀み流域の発生を避けるべき である。

運転温度が充分高い場合 (例えばTable 3 の下段の 3 箇 所）は，鋼種にかかわらず配管の内面はすべて不動態化 されているので，マクロセルは形成されない。逆に運転 温度が充分低い場合は, 鋼種にかかわらず配管の内面は すべて活性態であるのでマクロセルは形成されない。し たがって，実際に $120^{\circ} \mathrm{C}$ 程度であることが確認されれば 上記の対策は前述の 3 箇所以外の配管には無用である.

\section{8. 結言}

本文において著者が，当時の原因推定や再発防止対策 を執った事業所を批判していると感じられるとしたら， それは著者にとって誠に不本意である. 当事業所が行っ たこれらの処置が，当時では最適と考えられたものであ ることを著者は疑わない. 著者の断定的否定の表現は, その処置やその効果の可能性に向けられたものであっ て，その処置をとった事業所に向けられたものではない。 本事例の後に美浜事故が発生し, その経過と本事例のそ れとを比較検討することによって初めて本事例の原因に ついて新しい展開が生じた。また，この比較は美浜事故

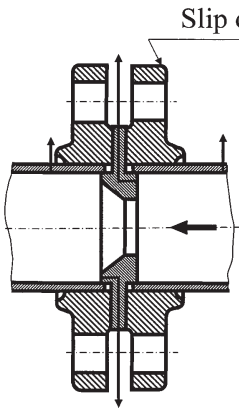

(a)

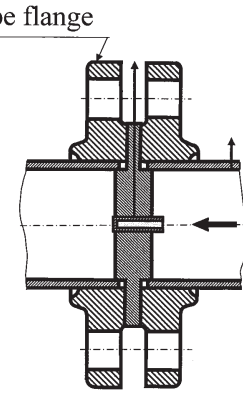

(b)

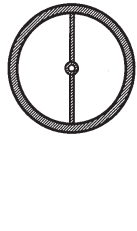

Fig. 6 Countermeasures for preventing the recurrence of corrosion damage. (a) Orifice of same material with the pipe. (b) Total pressure tube (Pitot tube).

の発生機構の確認に寄与するものと思われる.

このように良い意味でのシナジー効果が生まれたのは 美浜事故の詳細な調査結果がインターネット上に公開さ れたことにもよるが，次に挙げたこの事業所の敬服され るべき基本姿勢にもよる，第一に，発災箇所の詳細な調 査ばかりではなくその周辺の, 類似の箇所についても詳 細な調査を行ってその記録を残した．第二にその記録を 長期間保持し，第三に著者のぶしつけな要望に対して社 外には出しにくいその記録を提供し, しかもそれを広く 公表することを許して呉れたことである.

あらためて, 本事業所の安全・保安に対する意識の高 さと宽大さに心から敬意を表する次第である.

\section{参 考 文 献}

1) S. Yanagida and H. Kobayashi, J. High Press. Gas Saf. Inst. Jpn., 36, 720 (1999).

2) Research Report on Feed Water Pipe Line Disruptive Accident, HAO Co., Ltd. (1993).

3) Summary of the Final Report on the Secondary System Pipe Rupture at Unit 3, Mihama Nuclear Power Plant (NPP), Kansai Electric Power Co., (KEPCO) (April 18, 2005)-International Affairs Office, Nuclear and Industrial Safety Agency, Ministry of Economy trade and Industry.

4) Y. Huruya, M. Murakami and Y. Yamada, Ryuhtaikohgaku, Asakura-shoten, p.68 (1967).

5) F. Umemura and T. Kawamoto, Boshoku-Gijutsu (presently Zairyo-to-Kankyo), 30, 276 (1981).

6) O. de Bouvier, M. Bouchacourt and K. Fruzzetti,. Proceedings of the International Conference of Water Chemistry of Nuclear Reactor Systems, Avignon, France, 22-26, April (2002).

(Manuscript received June 26, 2006; in final form May 28, 2007)

\section{要旨}

本事例は，1993 年にある廃熱ボイラープラントで発生した。この事例は，2004 年に美浜原発で発生し た事例と, 配管材料, 環境条件および流量計の直ぐ下流に被害が発生したという点において共通の特徵を 持っている. 本事例については, 当時の最高の知見によって原因が解析され，最善と思われる再発防止策 が採られた. 事故発生から 7 年後の 2000 年に上記の再発防止策の効果が検討された。この検討の結果と, 新たに美浜の事例で得られた知見を合わせると, 異常減肉発生の原因は流れの乱れではなく, マクロセル 腐食にあるとする見解の合理性が確認された。

キーワード＼cjkstart乱れ，マクロセル腐食，ボイラー給水，異常減肉，炭素鋼鋼管 